\title{
Taxonomic account of genus Alternanthera (Amaranthaceae) in Jammu and Kashmir
}

\author{
Shugufta Rasheed ${ }^{1 *}$, Anzar A. Khuroo ${ }^{1}$, Aijaz H. Ganie², Zeenat Ismail', Muzamil Yousuf ${ }^{3}$, \\ T. H. Dar ${ }^{4}$ and Mohd S. Dar ${ }^{1}$
}

1. Centre for Biodiversity \& Taxonomy, Department of Botany, University of Kashmir, Srinagar-190 006, J \& K, India.

2. Department of Botany, University of Kashmir, Kargil Campus- 194105, J \& K, India.

3. Govt. Boys Higher Secondary School, Manigam -191201, J \& K, India 4. Centre for Biodiversity Studies, BGSB University, Rajouri -185131, J \& K, India. ${ }^{*}$ Corresponding author: shugufta922@gmail.com

\section{जम्मू एवं कश्मीर से ज्ञात वंश अल्टरनेंथेरा (अमरेंथेसी) का वर्गीकिय विवरण}

शुगुफ़्ता रशीद,अंज़र ए. खुरू, एज़ाज एच. गनी, मुज़म्मिल युसुफ़, टी.एच. डार मोहम्मद

\section{सारांश}

इस शोध पत्र में जम्मू एवं कश्मीर से ज्ञात वंश अल्टरनेंथेरा (अमरेंथेसी) का वर्गीकी विवरण प्रस्तुत किया गया है। वंश जो राज्य के चार जातियों अर्थात अल्टरनेंथेरा फिलोजेरोइड्स ग्रिसेब., अल्टरनेंथेरा सोसिलिज आर. बर एक्स डीसी, अल्टरनेंथेरा पंजेंस कुंथ, अल्टरनेंथेरा पेरोनीकोइड्स एवं अल्टरनेंथेरा पंजेंस से प्रतिलक्षित होती है। ये जातियां पहली बार इस राज्य से अभिलेखित की गई हुए हैं। इस शोध पत्र में एक संक्षिप्त विवरण, अद्यतन नामकरण, जातियों की कुंजी, ऋतुजैविकी एवं इसके नैदानिक लक्षणों के छायाचित्र प्रस्तुत किए गए हैं।

\begin{abstract}
A taxonomic account of the genus Alternanthera (Amaranthaceae) in the Union Territory of Jammu and Kashmir is presented here. The genus is represented by four species in the Union Territory i.e., Alternanthera philoxeroides Griseb., A. sessilis (L.) R.Br. ex DC., A. pungens Kunth and A. paronychioides A.St.Hil of which A. paronychioides and $A$. pungens are recorded for the first time from the Union Territory and Kashmir region, respectively. A brief description, updated nomenclature, key to the species, phenology and representative photographs are provided in the present communication.
\end{abstract}

Keywords: Flora, Kashmir, new records, nomenclature, Western Himalaya

\section{INTRODUCTION}

Alternanthera Forssk. (Amaranthaceae), a neotropical genus, with 80-200 species is the second largest genus in subfamily Gomphrenoideae of Amaranthaceae (Sa' nchez-del Pino \& al 2012). The genus is native to South America, Africa, Asia, and Australia (Mears, 1977, Robertson, 1981). Several species of the genus have been introduced in different parts of world (Sa'nchez-del Pino \& al 2012) and have become notorious invasive weeds. Members of this genus mainly colonize in wetlands and water bodies (Azzella \& al., 2013). Hooker (1897) reported two species i.e. A. sessilis (L.) R.Br. ex DC., and A. nodiflora R. Brown from Jammu and Kashmir (J\&K), India. Stewart (1972) reported one species i.e., A. sessilis R.Br. ex DC while Cook (1996) reported $A$. philoxeroides from J\&K. Kak (1990) reported A. peploides Urban from Kashmir valley which is now regarded as synonym of 
A. caracasana Kunth. In 2012, Masoodi and Khan reported A. philoxeroides (Mart.) Griseb from Kashmir Region. From Jammu region of J\&K, two species of this genus have been reported i.e., A. philoxeroides Griseb and A. pungens Kunth. Because of the confusing taxonomy, misidentifications, fragmented and scanty information of the genus available so far, the present study has revised the taxonomy of genus in $\mathrm{J} \& \mathrm{~K}$, with main aim of providing detailed taxonomic description, updated nomenclature, identification key, phenology and representative photographs of each species. In addition, the paper reports $A$. paronychioides as new plant record for the entire J \& K and $A$. pungens new plant record for Kashmir region.

\section{MATERIALS AND METHODS}

Jammu and Kashmir is a Union Territory located in the north-western part of India, with topography mostly of mountainous terrain. It consists of two regions: subtropical Jammu and the temperate Kashmir (Dar \& al., 2002). The study was carried during the years 20142018. Extensive surveys have been carried out in different parts of J \& K for the collection of specimens. Standard taxonomic methods have been used for collection, drying and further processing of the herbarium specimens (Bridson \& Forman, 1998). The processed herbarium specimens were deposited in the University of Kashmir Herbarium (KASH) with proper voucher specimen numbers. The information in regard to the distribution and habitat was obtained from previously deposited herbarium specimens. The photographs of the diagnostic characters were taken in the field with handheld portable microscope (Make: DINO Lite AM4515ZT4) and in the Laboratory with stereo-zoom microscope (Make: Leica S9D).

\section{TAXONOMIC TREATMENTS}

Alternanthera philoxeroides (Mart.) Griseb, Abh. Königl. Ges. Wiss. Göttingen 24: 36. 1879.(Fig. 1a, b)

Bucholzia philoxeroides Mart., Beitr. Amarantac.: 107. 1825.

Telanthera philoxeroides (Mart.) Moq. in DC., Prodr. 13:362. 1849.

Achyranthes philoxeroides (Mart.) Standl., J. Wash. Acad. Sci. 5: 74. 1915.

Perennial stoloniferous herb upto $75 \mathrm{~cm}$ high. Stems decumbent, ascending, becoming hollow and flattened with age, often much branched below, forming a mat, glabrous. Leaves paired, opposite, leaf blades linearelliptical, $5.5 \times 2 \mathrm{~cm}$, tapering at the base to form a short petiole-like base which clasps the stem, acute at the apex. Inflorescence cymose, head single in leaf axils or terminal, white, globose; peduncles up to $5.5 \mathrm{~cm}$ long. Bracts and bracteolate 1-2 mm long. Perianth segments \pm equal, glabrous, acute at apex. Stamens 5, alternating with fringed petaloid staminodes, filaments united below into a short tube or replaced by pseudoovaries. Fruit utricle.

Flowering and fruiting: June-October.

Habitat: It grows along shallow banks of water bodies and marshy areas.

Specimens examined: INDIA. Kashmir: District Srinagar, 07-08-2014, Anchar lake, Shugufta and Khuroo SR 194A, SR194B; District Srinagar, 09-082017, Dal lake, Shugufta and Khuroo SR 351.

Alternanthera sessilis (L.) R. Br. ex DC., Cat. Pl. Horti. Monsp.: 77. 1813.

Gomphrena sessilis L., Sp. Pl. 1:225. 1753.

Alternanthera triandra Lam., Encycl. 1:95. 1783.

Alternanthera nodiflora R. Br., Prodr. Fl. Nov. Holl.: 417. 1810.

Alternanthera repens Gmel., Syst. Nat., ed. 13., 2: 106. 1791.

Perennial herb upto $30 \mathrm{~cm}$ tall. Stem creeping, green or somewhat tinged purple, striped, hairy. Petiole $3 \mathrm{~mm}$, glabrous; leaf blade linear-lanceolate, oblong-obovate, or ovate-oblong, $5 \times 2 \mathrm{~cm}$, glabrous, base attenuate, margin entire, apex acute.Inflorescence cymose, heads axillary, sessile, at first globose later cylindric. Flowers dense, rachis densely white hairy. Bracts and bracteoles white, glabrous, apex acuminate; bracts ovatelanceolate; bracteoles subulate. Tepals white, ovate, 3 $\mathrm{mm}$ long, glabrous, with a vein, apex acuminate or acute. Stamens 3; filaments connate into a cup at base; anthers oblong; pseudostaminodes subulate, shorter than stamens, margin entire, apex acuminate. Style very short; stigma shortly parted. Utricle enclosed in perianth, obovoid, $2 \mathrm{~mm}$, dark brown. Seeds ovoid.

Flowering and fruiting: May-October.

Habitat: Grows in moist places in wastelands.

Specimens examined: India. Kashmir: 15-08-1970, Srinagar, Karan Nagar, Gurcharan Singh 175c; Srinagar, on the sides of drains, Unknown collector 

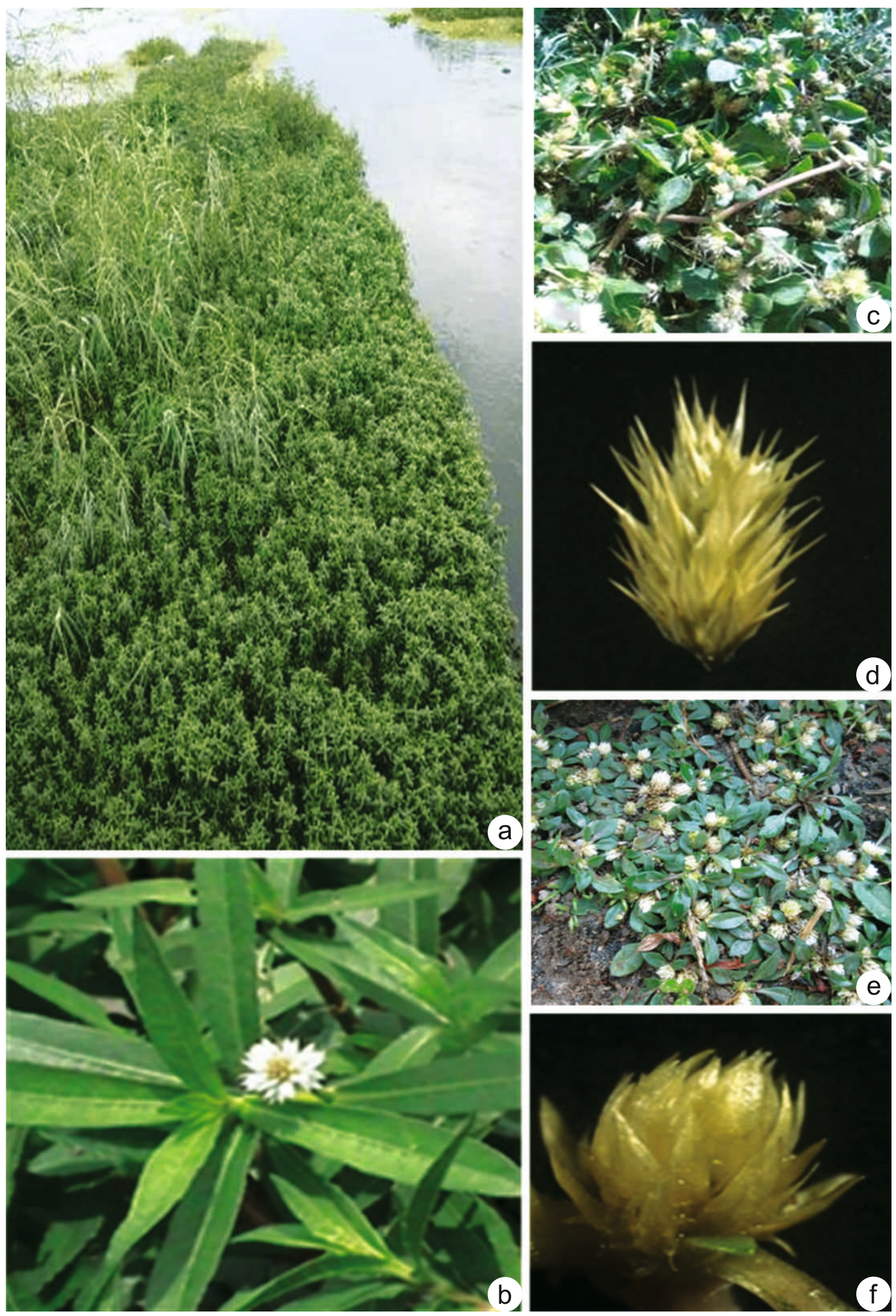

Fig. 1. Alternanthera philoxeroides Griseb.: a. Habit b. Inflorescence; A. pungens Kunth. c. Habit d. Inflorescence; A. paronychioides A. St.-Hil. e. Habitf. Inflorescence. 
659; 20-04-1988, Rajouri, G. H. Dar 9741; Jammu: 1004-1970, Nagrota, Borders of watery ditches, B. M. Sharma 472.

Alternanthera pungens Kunth, Nov. Gen. Sp. 2: 206. 1818.

(Fig. 1c, d )

Achyranthes repens L., Sp. Pl. 1:205. 1753.

Illecebrum achyrantha L., Sp. Pl., ed. 2. 1: 299. 1762.

Alternanthera achyrantha R. Br. ex Sweet, Hort. Suburb. Lond.: 48. 1818.

Alternanthera repens (L.) Link, Enum. Hort. Berol. Alt. 1: 154.1821.

Annual herbs upto $40 \mathrm{~cm}$ high. Stem diffuse, creeping, much branched, densely rigidly hairy. Petiole $1 \mathrm{~cm}$, hairy, leaf blade ovate, obovate, or elliptic-obovate, unequal in each pair, base acuminate, apex obtuse. Inflorescence cymose, heads sessile, axillary, white, globose or oblong. Bracts lanceolate, spiny at apex, bracteoles lanceolate, apex acuminate, without spines. Tepals unequal, outer 2 lanceolate, $5 \mathrm{~mm}$ long, 3-veined below, rigid after anthesis, midvein stretching into spines, central segment elliptic, $3.5 \mathrm{~mm}$ long, compressed, inner 2 small, enclosing ovary. Stamens 5; pseudostaminodes shorter than filaments, entire or irregularly dentate. Style very short. Utricle broadly ellipsoid, $1.5 \mathrm{~mm}$, brown.

Flowering and fruiting: May-October.

Habitat: It grows along roadsides.

Specimens examined: India. 16-10-2018, Kashmir: District Ganderbal, along roadside, Muzamil, Shugufta and Khuroo 928 \& 929; 10-08-1972, Jammu: Gandhi Nagar, roadside drains, B. M. Sharma 1271.

Alternanthera paronychioides A.St.-Hil., Voy. Distr. Diam. 2: 439. 1833.

(Fig. 1e, f)

Alternanthera leucantha Moq. in DC., Prodr. 13: 357. 1849.

Perennial herbs with a stout vertical rootstock. Stem densely barbellate hairy, glabrescent.Leaf blades asymmetric, spatulate, $1.5-2 \times 0.3-0.5 \mathrm{~cm}$, abaxially barbellate hairy, apex obtuse. Inflorescence cyme, heads sessile, ovoid to globose, hairy at base. Tepals white, ovate-oblong, scarious, hairy along veins, outer 3 segments: 3 -veined in proximal half, inner 2 somewhat laterally compressed, 1-veined, apex acute. Stamens 5; anthers yellow, ellipsoid; staminodes 3-or 4, toothed, $1 / 2$ as long as stamens. Stigma capitate. Utricle, brown, included within tepals, obcordate.
Flowering and fruiting: August-October.

Habitat: It grows on sandy, clayey or sandy loam sites.

Specimens examined: India. Kashmir: District Anantnag, Bijbehara, 23-10-2018, Shugufta and Khuroo 926, 927 (KASH).

Key to species

1a. Decumbent herb; heads with a peduncle, axillary ...A.philoxeroides

1b. Creeping herb; heads all sessile, axillary, rarely terminal $\ldots 2$

2a. Tepals abaxially hairy ...A. paronychioides

2b. Tepals abaxially glabrous $\quad . .3$

3a. Stamens 3; midvein of tepals not spiny at apex ...A. sessilis

3b. Stamens 5; midvein of tepals spiny at apex

...A. pungens

\section{ACKNOWLEDGMENTS}

The authors are thankful to Head, Department of Botany for providing necessary facilities. The supporting staff at the Centre for Biodiversity and Taxonomy, University of Kashmir is also acknowledged for their kind help during the course of present study. Funding received from MoEFCC (under AICOPTAX, F. No. 22018/12/ 2015/RE(Tax), Government of India, New Delhi to Anzar A. Khuroo is greatly acknowledged.

\section{REFERENCES}

AZZELLA, M.., M.IBERITE, M. FASCETTI, AND L. ROSATI 2013. Loss detection of aquatic habitats in Italian volcanic lakes using historical data. Plant Biosystems 147(2): 521-524.

BORSCH, T. 2001. Amaranthaceae. In: Stevens WD, Ulloa C, Pool A, Montiel O, eds. Flora de Nicaragua 1. Monographs in Systematic Botany from the Missouri Botanical Garden. pp.56-83.

BRIDSON, D. AND L.FORMAN 1998. The Herbarium Handbook. 3rd ed. Kew: Royal Botanic Gardens.

COOK, C.D.K. 1996. Aquatic and wetland plants of India. Oxford University Press, New Delhi.

DAR, G.H., R.C. BHAGAT AND M.A. KHAN 2002. Biodiversity of Kashmir. Valley Book House, University Road, Hazratbal, Srinagar. 
ESHETE, M.A.,Z. ASFAW, AND E. KELBESSA 2016. A review on taxonomic and use diversity of the family Amaranthaceae in Ethiopia. Journal of Medicinal Plants Sciences 4(2): 185-194.

HOOKER, J.D. 1897. Flora of British India.Vol.1.Bishen Singh Mahendra Pal Singh, Dehra Dun.1: 250-251.

IAMONICO, D. AND I. SÁNCHEZ-DEL PINO 2016. Taxonomic revision of the genus Alternanthera (Amaranthaceae) in Italy. Plant Biosystems 150(2):333342.

KAK, A.M. 1990. Aquatic and wetland vegetation of Kashmir Himalaya. Journal of Economic and Taxonomic Botany 14: 1-14.

MASOODI, A. AND F.A. KHAN 2012. Invasion of alligator weed (Alternanthera philoxeroides) in Wular Lake, Kashmir, India. Aquatic Invasions 7(1): 143-146.

MOODY, M.L., D.H. LESAND J.M. DITOMASO 2008. The role of plant systematic in invasive aquatic plant management. Journal of Aquatic Plant Management 46: 7-15.

MEARS, A.J. 1977. The nomenclature and type collections of the widespread taxa of Alternanthera (Amaranthaceae). Proceedings of the Academy of Natural Sciences of Philadelphia 129:1-21.

PEDERSEN, T.M. 1967. Studies in South American Amaranthaceae. Darwiniana 14: 430-463.
PEDERSEN, T.M. 1990. Studies in South American Amaranthaceae III (including one amphi-Atlantic species). Bulletin du Museum National d'Histoire Naturelle 12: 69-97.

PEDERSEN, T.M. 1997. Studies in South American Amaranthaceae IV. Adansonia 19:217-246.

PEDERSEN, T.M. 2000. Studies in South American Amaranthaceae V. Bonplandia 10: 83-112.

SA'NCHEZ-DEL PINO, I., T.J. MOTLEY AND T. BORSCH 2012. Molecular phylogenetics of Alternanthera (Gomphrenoideae, Amaranthaceae): resolving a complex taxonomic history caused by different interpretations of morphological characters in a lineage with $\mathrm{C} 4$ and $\mathrm{C} 3-\mathrm{C} 4$ intermediate species. Botanical Journal of the Linnean Society 169: 493-517.

ROBERTSON, K.R. 1981. The genera of Amaranthaceae in the southeastern United States. Journal of the Arnold Arboretum 62: 267-314.

STEWART, R. 1972. An annotated catalogue of vascular plants of West Pakistan and Kashmir. Fakhri Printing Press, Karachi.

TANVEER, A., A. KHALIQ AND M.H. SIDDIQUI. 2013. A review on genus Alternanthera weeds implications. Pakistan Journal of Weed Science Research 19(1):53-58. 